\title{
To compare dietary data using food portion sizes from 1988 and 2008
}

\author{
D. Bhakta and M. Warthon-Medina \\ London Metropolitan University, London N7 8DB, UK
}

There is evidence to suggest that increasing portion sizes, in part, contribute to the current obesity epidemic. In the USA the portion sizes of french fries, burgers and pizzas have increased and speculation is that this factor has led to an increase in energy and nutrient intake ${ }^{(1,2)}$. In the UK the most common method of determining portion size by nutritionists and dietitians is by using the Food Standard Agency's portion size ${ }^{(3)}$ handbook, which was first published in 1988. However, it is likely that portion size for certain foods may have changed over the 20-year period, and its current use by researchers may lead to the underestimation of energy and nutrient intake in individual and population dietary assessment. A list of food portions was compiled using the most recently available literature on portion sizes ${ }^{(4,5)}$ and a survey of foods from supermarkets and fast-food outlets was conducted.

Data were collected for nine major food categories: beverages, 13; biscuits, 25; confectionery, 24; cakes, buns and pastries, 39; meat and meat products, 65; pasta, rice and grains, 25; pudding, chilled desserts and fruit pies, 15; savoury snacks, 16; miscellaneous (chips, cheese and ice cream); 24. Overall, average portion sizes of commonly-consumed foods had increased and the range of portion sizes available had also increased. For example, an average glass of wine in 1988 measured $125 \mathrm{ml}$ whereas in 2008 it was $175 \mathrm{ml}$; only the standard bar of Cadbury's milk chocolate $(54 \mathrm{~g})$ was available in 1988, whereas in 2008 there were bars with weights of $49 \mathrm{~g}$, $250 \mathrm{~g}$ and $400 \mathrm{~g}$. Most notable increases in average portion sizes and portion size range were seen for fries, pizzas, crisps and burgers.

The effect of increasing portion sizes on the estimation of energy and nutrient intake was assessed by comparing data from $24 \mathrm{hr}$ recalls for sixteen nutrition students aged 21-42 years old. Total daily energy intake increased using portion sizes from $1988 v .2008$ (8728 (SD $3402) \mathrm{kJ}(2086$ (SD $745 \mathrm{kcal}) v$. (9606 (sD 3117) kJ (2296 (SD 813) kcal); $P=0.001)$. Significant differences $(P \leq 0.05)$ were also found for carbohydrate $(289 \mathrm{~g} v .314 \mathrm{~g})$, protein $(95 \mathrm{~g} v .104 \mathrm{~g})$, fat $(66 \mathrm{~g} v .76 \mathrm{~g})$, NSP $(18.1 \mathrm{~g} v .19 .1 \mathrm{~g})$ and Na $(2.3 \mathrm{~g} v .2 .6 \mathrm{~g})$ per day. These small but sustained increases in daily food intake could be a significant factor contributing to excess energy intake and adiposity ${ }^{(6)}$. These preliminary findings also suggest that there is a need to revise the Food Standard Agency's food portion size handbook to reflect 21 st century portion sizes.

1. Nielsen SJ \& Popkin BM (2003) J Am Med Assoc 289, 450-453.

2. Young LR \& Nestle M (2007) J Public Health Policy 28, 238-248.

3. Ministry of Agriculture Fisheries and Food (1988) Food Standards Agency. Food Portion Sizes, 3rd ed. [H Crawley, editor]. London: The Stationery Office.

4. Wrieden W, Gregor A \& Barton K (2008) Proc Nutr Soc 67, OCE6, E211.

5. Church S (2008) Trends in portion sizes in the UK - A preliminary review of published information. Report to the Food Standards Agency. http:// www.foodstandards.gov.uk/ (accessed June 2008).

6. Kelly MT, Wallace JMW, Robson P et al. (2009) Brit J Nutr Feb 16, 1-8 [Epub, ahead of print]. 